\title{
Psychological changes of Vietnamese farmers in the context of implementing market economy
}

\author{
Dung $\mathrm{Vu}^{1, *}$, and Minh Tuan Tran ${ }^{1}$ \\ ${ }^{1}$ Graduate Academy of Social Sciences, 477 Nguyen Trai Street, Hanoi, 10000, Vietnam
}

\begin{abstract}
Farmer psychology has been formed in line with the historical periods of Vietnamese society. This has exerted a great influence on the production and daily activities of farmers. This study aims to identify the psychological changes of Vietnamese farmers in the context of Vietnam's implementing market mechanisms on three aspects: Farmers' perceptions, emotions and behaviors. Our research results show that the majority of farmers in the survey have shown a change in awareness. They recognize the need to produce products that are marketed instead of consumed as before. Farmers today are no longer intimately attached to their fields and hometown as in the past. They are willing to do other jobs and go to other places with better incomes. Their behavior has shifted from subsistence production to commercial production
\end{abstract}

\section{Introduction}

Vietnamese farmers have always been an important social force of the country. In the past, farmers accounted for more than $80 \%$ of the national population. Until 2019, more than 60 million Vietnamese people live in rural areas, accounting for $65.6 \%$ of the population [General Statistics Office of Vietnam, 2019]. As such, famers' psychology has formed the core of Vietnamese psychology.

As Vietnam adopted market economy, Vietnam's socio-economic development has experienced historical changes. The drastic socio-economic changes have led to changes in the psychology of social classes, especially farmers, as the most populous class. The psychological changes of farmers are the result of changing production methods, social relations, and acculturation. The psychological changes of farmers have a great impact on the socio-economic development of the country in both directions: positive and negative.

The study of the psychological changes of Vietnamese farmers in the context of market economy has theoretical and practical implications. The results of this research contribute to the theoretical framework on psychological shifts of social classes and clarify the psychological portrait of Vietnamese farmers in modern society. This study also helps social managers to promote positive psychological characteristics and prevent negative mental health symptoms of Vietnamese farmers.

\footnotetext{
${ }^{*}$ Corresponding author: vudungtamly@gmail.com
} 
The market economy has significant impacts to agriculture all over the world. Binswanger-Mkhize (2014) assessed the impacts of land reform in South Africa on rural employment, demand for land, livelihoods and agricultural output [1]. While official programs has been carried out to support farmers, such as the Comprehensive Agricultural Support Programme; the programs was considered to be underperforming. An assessment of land reform's contribution to South Africa's pro-poor growth pattern revealed the limitations of the implementation of 12 land reform programs. Most peasants do not receive any benefits from their land, affecting agricultural production and food security [2]. Davis (2011) identified race differences in agricultural production: The black agricultural sector faces land destruction, including soil erosion, depletion of soil fertility, low productivity and yields, malnourished workers; while the white agricultural area which is characterized by large-scale agriculture, high capital, marketing and agricultural services, and easier access to credit [3]. Research on land redistribution and agricultural reform in South Africa showed that land redistribution significantly improves the livelihoods of the poor in rural areas and contributes to national economic development [4]. Research on the relationship between non-agriculturalization and pro-poor agricultural growth in 8 African countries between 2002 and 2008 showed that the pro-poor agricultural growth has so far focused on specific rural villages [5]. The policy challenge remains to devise strategies that can promote growth in marginal areas. Research on food and agriculture in Ethiopia pointed out many challenges of implementing poverty reduction policies, promoting economic growth and food safety [6]. With respect to food security, some countries are facing many challenges such as food price shocks, floods, droughts, diseases and people's health, food safety, nutrition, and the long-term consequences of recent food crises on food security and nutrition in developing countries [7]. Research on farm types and their economic characteristics in agroecosystems on the coastal West Bengal, India showed that agriculture is the mainstay of rural livelihoods and nearly $90 \%$ of cultivators are small and marginal farmers, jointly holding $84 \%$ of the State's agricultural land [8]. They cultivate rice for selfconsumption, not for sale. Concerning the commercialization of agriculture, in developing regions like Africa, agriculture has developed significantly over the past decades, but the increase is on land area instead of productivity [9]. Famers who were previously smallholder have become medium- and large-scale producers. This group of farmers plays an important role in the process of agricultural commercialization in Africa.

Along with changes in agricultural production, changes in farmers' psychology have attracted great attention from global and local researchers. Psychological research in the field of agricultural production analyzed farmers' choices, success, and satisfaction [10]. Research on farmers' aptitudes, interests and personality traits in running a farm has shown that individual competence is correlated with job performance and job satisfaction. Farmers who are extroverted with an optimistic view of life are more satisfied with their work [11]. Farmers' subjective perception of the farming process also affect productivity. For example, farmers' perceived prevalence of digital dermatitis disease in cows is lower than the actual rate [12]. A social psychological analysis of farmers, farming and change showed that the UK's agricultural sector is changing rapidly. The policy change, decoupling support payments from production, and social change have affected farmers 'awareness of food safety. Farmers pay more attention to environmental protection, responses to threats, and farming changes [13]. A study on farmer's mental health showed that farmers' mental health has recently become a global concern. Mental health disorders are more common in farmers and farmworkers. Farmers 'understanding of the psychosocial risk factors and their impact is essential to reducing farmers' mental illness [14]. Moreover, farmers' psychological capital is an important means for farm development. Psychological capital is expressed by farmers' level of confidence, hope, optimism, and resilience. It helps farmers to overcome difficulties, cope with challenges, and to develop sustainable livelihood strategies [15]. 
In Vietnam, there are a number of studies on farmers and farmer psychology. Initially, farmers' psychology was studied as a part of social psychology, such as village and community psychology [16], labor's psychology [17], women psychology [18]. Later, farmer psychology received more attention; and the psychological characteristics of farmers are studied as a distinct subject. Psychology of peri-urban farmers when rural areas are urbanized was studied through the aspects of demand, social awareness, communication changes, social relations, ability to adapt to urban lifestyles [19]. Ethnic minority farmers in the Central Highlands were analyzed in the survey project: Ethnic psychological factors affecting the development of the Central Highlands [20]. The basic psychological characteristics of farmers in the Central Highlands and the Southwest region were analyzed through the following aspects: Production capacity, communication, ethnic perceptions, character, and ethnic identity [21]. The psychology of ethnic minority farmers in the Northwest region of Vietnam was analyzed through the aspects of awareness, production capacity, communication, character, acculturation and ethnic identity [22]. Some basic psychological characteristics of Vietnamese peasantry were identified through awareness, attitudes, moods and beliefs of farmers [23].

In transition to market economy, farmer psychology focuses on farmers' difficulties and coping strategies. Rural labor and employment analyzed through the Annual Report on rural social development issues in 2009 showed about unemployment, migration as a livelihood strategy, and government poverty reduction policies [24]. A social attitutes survey of farmers in the Northern Delta on Vietnam's accession to the WTO analyzed some psychological aspects of farmers such as emotions, attitudes, beliefs, needs and livelihood orientation [25]. The acquisition of land for the construction of industrial parks has brought about a number of psychological issues for farmers such as farmers' satisfaction with compensation for land acquisition, changes of human-human relations, farmers 'moods, and attitudes, farmers' adaptive capacity after land acquisition [26]. In the Northwestern region, the poor farmers' mentality was expressed in the aspects of awareness, demand, capability, business and production actions [27]. The 2009 survey on Vietnamese farmers analyzed the aspects of land, production means, labor, and employment, farmers' income, expenditure and debt [24]. The 2010 survey on farmers was conducted in 4 provinces in the Red River Delta and the Mekong Delta in terms of average land areas and differences in the land between the North and the South, production means and labor. and employment, income, expenditure and debt, villages, farming families, social security [28]. Mechanisms and policies to support disadvantaged farmers in the process of shifting to the market mechanism in rural Vietnam were inspected through the impact of mechanisms and policies, and the difficulties in implementing policies supporting disadvantaged farmers [29]. Employment and income issues of rural youth were investigated through psychological aspects such as work motivation, needs, working style, adaptability and job satisfaction [30]. The research on social adaptation of disadvantaged groups in Vietnam examined the cognitive and behavioral adaptation of disadvantaged farmers [31]. Environmental ethical behavior of rural farmers is analyzed through the customary laws of ethnic minorities, pesticide use, mangrove deforestation, free migration and, deforestation, which destroyed farmers' environment [32]. The psychological characteristics of Protester farmers in ethnic minorities in the Central Highlands were studied from their perceptions, beliefs and religious behaviors [33]. The impact of farmers' psychology on the new rural construction in the Northern Delta region was evaluated through perceptions, attitudes, the psychology of smallholders and responsibilities of farmers [34]. The psychological transformation of farmers in the transition area (from commune to ward) was shown through: changing needs, changing perceptions and habits of farmers [35]. The efforts of Vietnamese farmers were analyzed through their beliefs, attitudes, feelings of happiness, and efforts to escape poverty [36]. Research on the interaction between farmers' 
psychology and the transformation to modern agricultural production methods was studied through farmers' perceptions, needs, cooperation capacity and the will to overcome difficulties [37]. Gender stereotypes about female farmers 'characteristics in the Red River Delta were analyzed through farmers' perceptions, emotions and behaviors [38]. The psychology of farmers in the Northern Delta was explored through the phenomenon of farmers abandoning their fields (farmers' satisfaction with land, attachment to the land, and their agricultural activities) [39].

The above studies show that farmers and agriculture issues are viewed from many different perspectives: national policies, land, production activities, farmers' psychology. However, there has not been an in-depth study of the psychological transformation of Vietnamese farmers in the context of implementing market mechanism and promoting international integration. This is the issue that this paper aims to analyze.

\section{Methods}

\subsection{Study area and sample selection}

After studying the natural conditions and production activities of farmers, we selected 5 provinces to survey, namely Thai Binh, Ben Tre, Hanoi, Tuyen Quang and Ha Tinh.

Thai Binh is a delta province in the North. Ben Tre is a delta province in the Southwest. These two provinces represent rural areas in the delta region with flat terrain, whose residents are mainly engaged in agricultural production. Hanoi is a large city with a dense population. This city has a number of agricultural production districts on the outskirts. Ba Vi District represents the rural areas in the suburbs. Tuyen Quang is a mountainous province in the North. Ha Tinh is a province that has Truong Son mountain range. These two provinces represent rural areas in the mountainous region, where agricultural production and transportation are difficult.

For each investigated province, we selected 1 commune. The total number of communes surveyed is 5 communes. The selection of communes for this survey is intentional sampling. Those survey areas are included in the survey activities of the ministerial-level project: The relationship between the state, the community, and the family in Vietnam, conducted in 2017 - 2018.

The total number of farmers surveyed was 600 people. Each commune has 120 people as representatives of farmers' families. The survey sample is selected by the stratified sampling method. For the selected farmers, we take into account gender, age, education, living standards, and place of residence to ensure that the number of target groups is not too different. After identifying different groups of farmers, we used a simple random sampling method.

Socio-demographic characteristics of the research sample are reflected in the following data table:

Table 1. Characteristics of the research sample.

\begin{tabular}{|c|c|}
\hline Characteristics & N (\%) \\
\hline Gender & $336(56,0 \%)$ \\
\hline Male & $264(44,0 \%)$ \\
\hline Female & \\
\hline Age & $134(22.3 \%)$ \\
\hline$<30$ years old & $412(68.7 \%)$ \\
\hline $30-49$ years old & $54(9.0 \%)$ \\
\hline $50-70$ years old & \\
\hline Academic level & \\
\hline
\end{tabular}




\begin{tabular}{|c|c|}
\hline Primary & $114(19.0 \%)$ \\
\hline Lower secondary & $263(43.8 \%)$ \\
\hline Upper secondary & $183(30.5 \%)$ \\
\hline Post-secondary & $40(6.7 \%)$ \\
\hline Place of residence & $200(33.3 \%)$ \\
\hline Delta rural areas & $200(33.3 \%)$ \\
\hline Suburban rural areas & $200(33 . \%)$ \\
\hline Mountainous rural areas & \\
\hline Standard of living & $175(29.2 \%)$ \\
\hline Well off & $379(63.2 \%)$ \\
\hline Adequate & $46(7.7 \%)$ \\
\hline Inadequate &
\end{tabular}

Table 1 shows that the research sample is gender-balanced (56\% male, $44 \%$ female). The majority of the research sample is middle-aged people from $30-49$ years old $(68.7 \%)$, graduated from lower secondary and upper secondary school $(43.8 \%$ and $30.5 \%$ respectively) and with an adequate standard of living (63.2\%). The sample structure reflects the practical characteristics of farmers in rural Vietnam for the time being, when most young adults work away from home. In the rural areas, the remaining people are mostly middle-aged farmers who have an adequate standard of living and academic level.

\subsection{Research method}

This study is based on the hypothesis that changes in agricultural production and living conditions have changed the farmers' psychology in the context of transition to market mechanisms. The change of farmers' psychology exists in tandem with the old psychology of farmers (smallholder psychology). The psychological change has a positive effect while the existence of the old psychology has a negative impact on agricultural production.

Farmers' psychological change in this paper is defined as a change in farmers' perceptions, emotions, and behaviors to adapt to market mechanisms and to promote production.

Farmer interview questionnaire

The questionnaire measures the psychological change of farmers in the context of market mechanisms and globalization. The questionnaire consists of 3 sub-sets: the change in farmers' awareness, the change in farmers' emotion and the change in farmers' behavior. Each sub-set consists of 4-5 questions, each question consists of 3 items, of which the first item shows the attachment to the old perceptions, emotions and behaviors; the second item represents partial acceptance of market-oriented perceptions, emotions and behaviors, and the third item represents the complete acceptance of market-oriented perceptions, emotions and behaviors. For each question, the subject answers by choosing 1 of the 3 items, and evaluate the level of agreement with the statement on that item on a 5-point Likert scale (1 not agree - 5 very agree).

The subset measuring the changes in farmers' perceptions include 4 questions about: changing perceptions of production thinking; changing perceptions of production restructuring; changing perceptions of applying scientific and technological advances to production; and changing perceptions of getting rich and doing business.

The subset measuring the changes in farmers' emotions include 4 questions about: Attachment to fields; Attachment to agriculture; Attachment to the village; changes in the neighborly relationship.

Independent variables affect the changes in farmers' psychology 
The questionnaire was also designed to measure the relationship between the independent variables (gender, age, education, place of residence and family living standard) and changes in farmers' psychology (perceptions, emotions, and behavior).

The questionnaire was surveyed in 2 stages; 1) The pilot survey of 20 families to adjust the items in the questionnaire to suit the target audience; 2) Official survey after the questionnaire has been edited.

Statistical analysis

To analyze the dependent variables, we put weight on each item. Items that show attachment to the old perceptions, emotions and behaviors are put weight by 1 (raw score $\mathrm{x}$ 1). Items that express a partial acceptance of market-oriented perceptions, emotions and behaviors are put weight by 2 (raw score x 2). Items indicating complete acceptance of market-oriented perceptions, emotions and behaviors are put weight by 3 (raw score $\mathrm{x} 3$ ). The average score of each subset is calculated by the average score of the items in the subset after multiplying with the weight.

\section{Results and Discussion}

\subsection{Traditional Vietnamese agricultural economy, the psychology of Vietnamese farmers in history and the transition to market mechanisms in Vietnam}

For thousands of years, Vietnamese society was a feudal society with small-scale, selfsufficient production with peasantry accounting for more than $80 \%$ of the population. The traditional Vietnamese agricultural economy has the following basic characteristics: (1) It is an economy derived from a communal economy. The communal economy can be seen from the fact that all land, resources within its territories are the common property of every member of the village, controlled and governed by the village. Every member of the village enjoys that common property and is responsible for protecting that economy. (2) The traditional Vietnamese agricultural economy is the one that attaches importance to agriculture with self-sufficient production. The feudal society of Vietnam is basically a society that "respects agriculture and overlook trade", i.e. attaches importance to agriculture, and overlooks business and trading activities. All products made by families are for family use only. If sold, those products are only in the village market, not exchanged with other villages. Each village controls its own economic machine and is closed to outsiders. (3) The traditional Vietnamese agricultural economy is a fragmented, backward economy with low accumulation capacity. The fragmentation of production is evident in the fact that each family has only a few acres of farmland. The farming farmland is scattered. The production tools of farmers are very simple. These are the tools used by hand, such as ard plow, harrows, hoes, sickles, etc. Farmers mainly use practical knowledge and experience to plant and raise animals. That backward economy always faces natural disasters (storms, floods, droughts) and epidemics. Therefore, farmers' families have very little capacity to store, expand production and improve their prosperity [18, 20, 23].

A traditional agricultural economy that has existed for thousands of years has created a specific form of the psychology of Vietnamese farmers - Psychology of small farmers. This form of psychology has the following characteristics: (1) The thinking of Vietnamese farmers in the past is small and fragmented. This is the thinking without foresight nor big business thinking, only focus on the immediate and specific needs (2) Farmers value community, showing little of their selves. The communal economy has created a psychological trait of valuing the community. The self of individuals is dissolved into the community and obscured by the community. The locality of villages and families of the 
farmers is clearly shown. (3) The low discipline of the farmers values sentiment more than logic. The small, fragmented farming method creates a personal working habit for each family, which makes the social awareness of law low among farmers. Farmers mainly follow village conventions and rules. This also creates a social behavior of farmers, which attaches more importance to social relations than social norms. (4) Village love and neighborly relationship are respected by farmers. In a life of poverty, deprivation, natural disasters, epidemics, it is essential and indispensable for families in the village to live codependently. There are Vietnamese old sayings: "Tình làng, nghĩa xóm", which means you should have a good relationship with your neighbors because they are the one aiding you in time of need; or "Bầu ơi thương lấy bí cùng, tuy rằng khác giống nhưng chung một giàn", which means we all bleed the same and we should protect and be altruistic to each other.

In 1986, the Party-state launched the "Doi Moi" or all-round renovation policy, switching from a subsidized centralized economy to a market mechanism. It is a transition from a highly centralized and planned economy with state and collective economic sectors to a commodity and market economy with a diversity of economic sectors. It is an open economy, integrated with the region and the world. The economic transformation has created an extensive change and development of Vietnamese society. The material and spiritual life of farmers' families has been increasingly improved. In the past, farmers' worries were about the problem of having enough food and clothes, now this has changed to the thinking of "eating well, wearing nice". The dramatic change in social life leads to a certain change in farmers' psychology.

\subsection{Shift in farmers' perception in the context of implementing market mechanisms}

The survey results of the changing perceptions of farmers are reflected in the following table:

Table 2. The changing perceptions of farmers.

\begin{tabular}{|c|c|c|c|c|c|c|c|}
\hline \multirow[b]{2}{*}{$\begin{array}{l}\text { Aspects relating to farmers' } \\
\text { perceptions }\end{array}$} & \multirow[b]{2}{*}{$\mathrm{N}(\%)$} & \multirow[b]{2}{*}{$\begin{array}{l}\mathrm{M} \\
(\mathrm{SD})\end{array}$} & \multicolumn{5}{|c|}{$\mathrm{N}$ and $\%$ of choice } \\
\hline & & & $\begin{array}{l}\text { Incor } \\
\text { rect }\end{array}$ & $\begin{array}{c}\text { Some } \\
\text { what } \\
\text { correc } \\
\mathrm{t}\end{array}$ & $\begin{array}{l}\text { Quite } \\
\text { correct }\end{array}$ & Correct & $\begin{array}{l}\text { Exactly } \\
\text { correct }\end{array}$ \\
\hline \multicolumn{8}{|l|}{ 1. Production thinking } \\
\hline $\begin{array}{l}\text { 1.1. Keep the thinking of self- } \\
\text { sufficient farming through } \\
\text { cultivation and husbandry }\end{array}$ & $\begin{array}{c}154 \\
(25.7 \% \\
)\end{array}$ & $\begin{array}{c}3.90 \\
(0.31)\end{array}$ & 0 & 0 & $\begin{array}{c}16 \\
(10.4 \% \\
\quad) \\
\end{array}$ & $\begin{array}{c}138 \\
(89.6 \% \\
)\end{array}$ & 0 \\
\hline $\begin{array}{l}\text { 1.2. Agricultural produce made by } \\
\text { the family are mainly for daily life }\end{array}$ & $\begin{array}{c}294 \\
(49.0 \%\end{array}$ & $\begin{array}{c}3.58 \\
(0.49)\end{array}$ & 0 & 0 & $\begin{array}{c}124 \\
(42.2 \% \\
)\end{array}$ & $\begin{array}{c}170 \\
(57.8 \% \\
)\end{array}$ & 0 \\
\hline $\begin{array}{l}\text { 1.3.In cultivation and husbandry, } \\
\text { the family needs to change from } \\
\text { the mindset of self-sufficient } \\
\text { producers to market-oriented } \\
\text { producers. }\end{array}$ & $\begin{array}{c}152 \\
(25.3 \% \\
)\end{array}$ & $\begin{array}{c}3.45 \\
(0.50)\end{array}$ & 0 & 0 & $\begin{array}{c}83 \\
(54.6 \% \\
\quad)\end{array}$ & $\begin{array}{c}69 \\
(45.4 \% \\
)\end{array}$ & 0 \\
\hline Total & $\begin{array}{c}600 \\
(100 \%)\end{array}$ & & & & & & \\
\hline \multicolumn{8}{|l|}{ 2.Production restructuring } \\
\hline $\begin{array}{l}\text { 2.1.There is no need to restructure } \\
\text { livestock and crops because doing } \\
\text { business as previously is suitable } \\
\text { for the family }\end{array}$ & 0 & 0 & 0 & 0 & 0 & 0 & 0 \\
\hline $\begin{array}{l}\text { 2.2. My family needs to } \\
\text { restructure livestock and crops to }\end{array}$ & $\begin{array}{c}326 \\
(54.3 \% \\
\end{array}$ & $\begin{array}{c}3.86 \\
(0.50) \\
\end{array}$ & 0 & 0 & $\begin{array}{c}67 \\
(20.6 \% \\
\end{array}$ & $\begin{array}{c}239 \\
(73.3 \% \\
\end{array}$ & $\begin{array}{c}20 \\
(6.1 \%) \\
\end{array}$ \\
\hline
\end{tabular}




\begin{tabular}{|c|c|c|c|c|c|c|c|}
\hline $\begin{array}{l}\text { increase labor productivity, } \\
\text { quality and economic efficiency } \\
\text { of the product. }\end{array}$ & ) & & & & ) & ) & \\
\hline $\begin{array}{l}\text { 2.3.My family needs to restructure } \\
\text { livestock and crops so that the } \\
\text { products can be sold in the market }\end{array}$ & $\begin{array}{c}274 \\
(45.7 \% \\
)\end{array}$ & $\begin{array}{c}3.92 \\
(0.62)\end{array}$ & 0 & 0 & $\begin{array}{c}64 \\
(23.4 \% \\
)\end{array}$ & $\begin{array}{c}168 \\
(61.3 \% \\
)\end{array}$ & $\begin{array}{c}42 \\
(15.3 \% \\
)\end{array}$ \\
\hline Total & $\begin{array}{c}600 \\
(100 \%)\end{array}$ & & & & & & \\
\hline $\begin{array}{l}\text { 3.Applying scientific and } \\
\text { technological advances to } \\
\text { production }\end{array}$ & & & & & & & \\
\hline $\begin{array}{l}\text { 3.1.There is no need to apply } \\
\text { scientific and technological } \\
\text { advances to production because } \\
\text { the family still keeps the } \\
\text { traditional method of production } \\
\text { based on practical knowledge and } \\
\text { experience }\end{array}$ & $\begin{array}{l}218 \\
(36.3 \% \\
\quad)\end{array}$ & $\begin{array}{c}3.50 \\
(0.50)\end{array}$ & 0 & 0 & $\begin{array}{c}109 \\
(50 \%)\end{array}$ & $\begin{array}{c}109 \\
(50 \%)\end{array}$ & 0 \\
\hline $\begin{array}{l}\text { 3.2.My family needs to apply } \\
\text { science and technology to } \\
\text { production because it is an } \\
\text { important factor to increase labor } \\
\text { productivity. }\end{array}$ & $\begin{array}{c}283 \\
(47.2 \% \\
)\end{array}$ & $\begin{array}{c}3.36 \\
(0.55)\end{array}$ & 0 & 0 & $\begin{array}{c}191 \\
(67.5 \% \\
\quad)\end{array}$ & $\begin{array}{c}82 \\
(29.0 \% \\
)\end{array}$ & $\begin{array}{c}10 \\
(3.5 \%)\end{array}$ \\
\hline $\begin{array}{l}\text { 3.3.My family needs to apply } \\
\text { science and technology to } \\
\text { production because it is an } \\
\text { important factor to increase } \\
\text { product quality, and to solve the } \\
\text { problem of product output }\end{array}$ & $\begin{array}{c}99 \\
(16.5 \% \\
\quad)\end{array}$ & $\begin{array}{c}3.90 \\
(0.30)\end{array}$ & 0 & 0 & $\begin{array}{c}10 \\
(10.1 \% \\
)\end{array}$ & $\begin{array}{c}89 \\
(89.9 \% \\
)\end{array}$ & 0 \\
\hline Total & $\begin{array}{c}600 \\
(100 \%)\end{array}$ & & & & & & \\
\hline \multicolumn{8}{|l|}{$\begin{array}{l}\text { 4.Perceptions of making money } \\
\text { and doing business }\end{array}$} \\
\hline $\begin{array}{l}\text { 4.1.Doing business and making } \\
\text { money do not fit with the village } \\
\text { tradition }\end{array}$ & $\begin{array}{c}43 \\
(7.2 \%)\end{array}$ & $\begin{array}{c}4.00 \\
(0.00)\end{array}$ & 0 & 0 & 0 & $\begin{array}{c}43 \\
(100 \%)\end{array}$ & 0 \\
\hline $\begin{array}{l}\text { 4.2.Doing business and making } \\
\text { money need to be accepted } \\
\text { because this is suitable for the } \\
\text { market and integration of the } \\
\text { country }\end{array}$ & $\begin{array}{c}320 \\
(53.3 \% \\
)\end{array}$ & $\begin{array}{c}3.63 \\
(0.48)\end{array}$ & 0 & 0 & $\begin{array}{c}120 \\
(37.5 \% \\
)\end{array}$ & $\begin{array}{c}200 \\
(62.5 \% \\
)\end{array}$ & 0 \\
\hline $\begin{array}{l}\text { 4.3. Doing business and making } \\
\text { money open the way to fullness, } \\
\text { developing the country and local } \\
\text { economy }\end{array}$ & $\begin{array}{c}237 \\
(39.5 \% \\
)\end{array}$ & $\begin{array}{c}3.58 \\
(0.49)\end{array}$ & 0 & 0 & $\begin{array}{c}100 \\
(42.2 \% \\
)\end{array}$ & $\begin{array}{c}137 \\
(57.8 \% \\
)\end{array}$ & 0 \\
\hline Total & $\begin{array}{c}600 \\
(100 \%)\end{array}$ & & & & & & \\
\hline
\end{tabular}

Table 2 shows that in all 4 aspects relating to the farmers' perceptions, the majority of respondents chose the second item, which can be seen from the highest percentage and the average score of the second item among 4 questions. In other words, the majority of farmers partially accept the market economy perceptions. The rate of selecting the first item is lowest in the aspects of "production restructuring" $(0 \%)$ and "perceptions of doing business and making money" $(7.2 \%, \mathrm{M}=4.0)$. Those show the most noticeable sign of the changes in farmers' perceptions. The proportion of selecting the third item is highest in the aspect of " production restructuring" $(45.7 \%, \mathrm{M}=3.92)$. Notably, the rating for "exactly correct" level was also the highest in this item (15.3\%) among all four aspects, suggesting that a shift to market economy thinking is manifested in the perception of production restructuring, with a large proportion of farmers saying that the family needs to change the structure of livestock and crops so that the product can be sold in the market. 


\section{Shift in farmers' emotions in the context of implementing market mechanisms}

The survey results of the changing emotions of farmers are reflected in the following table:

Table 3. The changing emotions of farmers.

\begin{tabular}{|c|c|c|c|c|c|c|c|}
\hline \multirow[b]{2}{*}{ Aspects relating to farmers' emotions } & \multirow[b]{2}{*}{$\mathrm{N}(\%)$} & \multirow[b]{2}{*}{$\mathrm{M}(\mathrm{SD})$} & \multicolumn{5}{|c|}{$\mathrm{N}$ and $\%$ of choice } \\
\hline & & & $\begin{array}{c}\text { Incor } \\
\text { rect }\end{array}$ & \begin{tabular}{|c|} 
Some- \\
what \\
correct
\end{tabular} & $\begin{array}{c}\text { Quite } \\
\text { correct }\end{array}$ & Correct & $\begin{array}{l}\text { Exactly } \\
\text { correct }\end{array}$ \\
\hline \multicolumn{8}{|l|}{ 1.Attachment to fields } \\
\hline $\begin{array}{c}\text { 1.1.My family is attached to the fields in our } \\
\text { whole life, because it is the flesh and blood of a } \\
\text { farmer }\end{array}$ & $\begin{array}{c}184 \\
(30.7 \% \\
)\end{array}$ & $\begin{array}{c}3.88 \\
(0.33)\end{array}$ & 0 & 0 & $\begin{array}{c}22 \\
(12.0 \% \\
)\end{array}$ & $\begin{array}{c}162 \\
(88.0 \% \\
)\end{array}$ & 0 \\
\hline $\begin{array}{l}\text { 1.2.My family today is no longer attached to the } \\
\text { field, because the field is no longer the most } \\
\text { important for farmers }\end{array}$ & $\begin{array}{c}306 \\
(51.0 \% \\
)\end{array}$ & $\begin{array}{c}3.72 \\
(0.60)\end{array}$ & 0 & 0 & $\begin{array}{c}111 \\
(36.6 \% \\
)\end{array}$ & $\begin{array}{c}171 \\
(55.9 \% \\
)\end{array}$ & $24(7.8 \%)$ \\
\hline $\begin{array}{l}\text { 1.3. Young adult descendants of the family go to } \\
\text { the city to look for jobs or work in industrial } \\
\text { parks. Land fields of the family will be for rent } \\
\text { or abandoned. }\end{array}$ & $\begin{array}{c}110 \\
(18.3 \% \\
\quad)\end{array}$ & $\begin{array}{c}3.84 \\
(0.37)\end{array}$ & 0 & 0 & $\begin{array}{c}18 \\
(16.4 \% \\
)\end{array}$ & $\begin{array}{c}92 \\
(83.6 \% \\
)\end{array}$ & 0 \\
\hline Total & $\begin{array}{c}600 \\
(100 \%)\end{array}$ & & & & & & \\
\hline \multicolumn{8}{|l|}{ 2.Attachment to agriculture } \\
\hline $\begin{array}{c}\text { 2.1.My family is engaged in agriculture for our } \\
\text { whole life, because it is so ingrained in our } \\
\text { lives that we do not want to change }\end{array}$ & $\begin{array}{c}97 \\
(16.2 \% \\
)\end{array}$ & $\begin{array}{c}4.28 \\
(0.61)\end{array}$ & 0 & 0 & $\begin{array}{c}8 \\
(8.2 \%)\end{array}$ & $\begin{array}{c}54 \\
(55.7 \% \\
)\end{array}$ & $\begin{array}{c}35 \\
(36.1 \%)\end{array}$ \\
\hline $\begin{array}{c}\text { 2.2.My family is only attached partly to } \\
\text { agriculture. We can turn to some service } \\
\text { activities, not necessarily devoted our whole } \\
\text { life to agriculture. }\end{array}$ & $\begin{array}{c}358 \\
(59.7 \% \\
\quad)\end{array}$ & $\begin{array}{c}3.63 \\
(0.48)\end{array}$ & 0 & 0 & $\begin{array}{c}133 \\
(37.2 \% \\
)\end{array}$ & $\begin{array}{c}225 \\
(62.8 \% \\
)\end{array}$ & 0 \\
\hline $\begin{array}{l}\text { 2.3.Today, there are many jobs with better } \\
\text { incomes than farming, so my family no longer } \\
\text { works in agriculture }\end{array}$ & $\begin{array}{c}145 \\
(24.2 \% \\
)\end{array}$ & $\begin{array}{c}4.14 \\
(0.74)\end{array}$ & 0 & 0 & $\begin{array}{c}30 \\
(20.7 \% \\
\end{array}$ & $\begin{array}{c}64 \\
(44.1 \% \\
)\end{array}$ & $\begin{array}{c}51 \\
(35.2 \%)\end{array}$ \\
\hline Total & $\begin{array}{c}600 \\
(100 \%) \\
\end{array}$ & & & & & & \\
\hline \multicolumn{8}{|l|}{ 3.Attachment to village } \\
\hline $\begin{array}{l}\text { 3.1.My family never wants to leave the village, } \\
\text { because many generations have been in the } \\
\text { village. It is our homeland, our ancestral land. }\end{array}$ & $\begin{array}{c}194 \\
(32.3 \% \\
)\end{array}$ & $\begin{array}{c}4.72 \\
(0.45)\end{array}$ & 0 & 0 & 0 & $\begin{array}{c}54 \\
(27.8)\end{array}$ & $\begin{array}{c}140 \\
(72.2)\end{array}$ \\
\hline $\begin{array}{c}\text { 3.2.My family is only partly attached tothe } \\
\text { village. When conditions permit, we will leave } \\
\text { the village to go to work elsewhere for a better } \\
\text { income }\end{array}$ & $\begin{array}{c}365 \\
(60.8 \% \\
\quad)\end{array}$ & $\begin{array}{c}4.24 \\
(0.48)\end{array}$ & 0 & 0 & $\begin{array}{c}9 \\
(2.5 \%)\end{array}$ & $\begin{array}{c}261 \\
(71.5 \% \\
)\end{array}$ & $\begin{array}{c}95 \\
(26.0 \%)\end{array}$ \\
\hline $\begin{array}{l}\text { 3.3. Currently, our descendants either work in } \\
\text { another city or province or are willing to reside } \\
\text { in places with better living conditions. }\end{array}$ & $\begin{array}{c}41 \\
(6.8 \%)\end{array}$ & $\begin{array}{c}4.05 \\
(0.22)\end{array}$ & 0 & 0 & 0 & $\begin{array}{c}39 \\
(95.1 \% \\
)\end{array}$ & $\begin{array}{c}2 \\
(4.9 \%)\end{array}$ \\
\hline Total & $\begin{array}{c}600 \\
(100 \%) \\
\end{array}$ & & & & & & \\
\hline \multicolumn{8}{|l|}{ 4.Changes in community relationships } \\
\hline $\begin{array}{l}\text { 4.1.Village love and neighborly relationships } \\
\text { are still the same as in the past. Everyone cares } \\
\text { and helps others in need. }\end{array}$ & $\begin{array}{c}211 \\
(35.2 \% \\
)\end{array}$ & $\begin{array}{c}4.02 \\
(0.14)\end{array}$ & 0 & 0 & 0 & $\begin{array}{c}207 \\
(98.1)\end{array}$ & $\begin{array}{c}4 \\
(1.9 \%)\end{array}$ \\
\hline $\begin{array}{l}\text { 4.2. Village love and neighborly relationships } \\
\text { has changed to some extend. Basically, people } \\
\text { still cares and helps others in need }\end{array}$ & $\begin{array}{c}318 \\
(53.0 \% \\
)\end{array}$ & $\begin{array}{c}3.93 \\
(0.28)\end{array}$ & 0 & 0 & $\begin{array}{c}24 \\
(7.5 \%)\end{array}$ & $\begin{array}{c}291 \\
(91.5 \% \\
)\end{array}$ & $\begin{array}{c}3 \\
(0.9 \%)\end{array}$ \\
\hline $\begin{array}{l}\text { 4.3. Village love and neighborly relationships } \\
\text { has changed a lot. People often only care about } \\
\text { their own. }\end{array}$ & $\begin{array}{c}71 \\
(11.8 \% \\
)\end{array}$ & $\begin{array}{c}4.00 \\
(0.00)\end{array}$ & 0 & 0 & 0 & $\begin{array}{c}71 \\
(100 \%)\end{array}$ & 0 \\
\hline ( & $\begin{array}{c}600 \\
(100 \%)\end{array}$ & & & & & & \\
\hline
\end{tabular}




\section{INTERAGROMASH 2020}

Table 3 shows that in all 4 aspects relating to the farmers' emotions, the majority of respondents chose the second item, which can be seen from the far higher percentage of choice than the other 2 items in all 4 questions. Thus, people's feelings for the countryside and traditional values of the countryside are changing in the direction of reducing the adherence to traditional values, increasing acceptance of new values, new habits, new way of life. The rate of selecting the first item is lowest in the aspect of 'attachment to agriculture' $(16.2 \%, \mathrm{M}=4.28)$, showing the most significant emotional change in the decreased attachment to farming and agriculture. This content also has the highest percentage of choice for the third item $(24.2 \%, \mathrm{M}=4.14)$. Thus, farmers are gradually switching to service activities instead of adhering to agricultural production, or eliminating agriculture entirely. The second most significant change lies in the aspect of "attachment to the field", with $18.3 \%$ of respondents choosing the third item.

\section{Shift in farmers' perception in the context of implementing market mechanisms}

The survey results of the changing behaviors of farmers are reflected in the following table:

Table 4. The changing behaviors of farmers.

\begin{tabular}{|c|c|c|c|c|c|c|c|}
\hline \multirow[b]{2}{*}{$\begin{array}{c}\text { Aspects relating to farmers' } \\
\text { behaviors }\end{array}$} & \multirow[b]{2}{*}{ N (\%) } & \multirow[b]{2}{*}{$\mathrm{M}(\mathrm{SD})$} & \multicolumn{5}{|c|}{$\mathrm{N}$ and $\%$ of choice } \\
\hline & & & $\begin{array}{c}\text { Incor- } \\
\text { rect }\end{array}$ & $\begin{array}{l}\text { Some- } \\
\text { what } \\
\text { correct }\end{array}$ & $\begin{array}{l}\text { Quite } \\
\text { correct }\end{array}$ & Correct & $\begin{array}{l}\text { Exactly } \\
\text { correct }\end{array}$ \\
\hline \multicolumn{8}{|l|}{ 1.Crop and livestock restructuring } \\
\hline $\begin{array}{l}\text { 1.1.My family still maintains rice } \\
\text { and other crops, raising the animals } \\
\text { as before, mainly for family to } \\
\text { consume and only sell a part. }\end{array}$ & $\begin{array}{c}79 \\
(13.2 \%)\end{array}$ & $\begin{array}{l}4.00 \\
(0.00)\end{array}$ & 0 & 0 & 0 & $\begin{array}{c}79 \\
(100 \%)\end{array}$ & 0 \\
\hline $\begin{array}{l}\text { 1.2.My family has turned to high } \\
\text { yielding crops and fruits to sell }\end{array}$ & $\begin{array}{c}314 \\
(52.3 \%)\end{array}$ & $\begin{array}{c}3.89 \\
(0.42)\end{array}$ & 0 & $\begin{array}{c}13 \\
(4.1 \%)\end{array}$ & $\begin{array}{c}8 \\
(2.5 \%)\end{array}$ & \begin{tabular}{|c|}
293 \\
$(93.3 \%)$
\end{tabular} & 0 \\
\hline $\begin{array}{l}\text { 1.3.My family raise animals that } \\
\text { produce goodquality meat and high } \\
\text { economic efficiency to sell }\end{array}$ & $\begin{array}{c}207 \\
(34.5 \%)\end{array}$ & $\begin{array}{l}4.00 \\
(0.00)\end{array}$ & 0 & 0 & 0 & $\begin{array}{c}207 \\
(100 \%)\end{array}$ & 0 \\
\hline Total & $\begin{array}{c}600 \\
(100 \%)\end{array}$ & & & & & & \\
\hline \multicolumn{8}{|l|}{$\begin{array}{l}\text { 2. Attachment to fields and } \\
\text { homeland }\end{array}$} \\
\hline $\begin{array}{l}\text { 2.1.My family is still attached to } \\
\text { the fields and some traditional jobs } \\
\text { of farmers (plowing, planting, } \\
\text { raising pigs, chickens, fishes ...) }\end{array}$ & $\begin{array}{c}25 \\
(4.2 \%)\end{array}$ & $\begin{array}{c}4.08 \\
(0.76 \%)\end{array}$ & 0 & 0 & $\begin{array}{c}6 \\
(24.0 \%)\end{array}$ & $\begin{array}{c}11 \\
(44.0 \%)\end{array}$ & $8(32.0 \%)$ \\
\hline $\begin{array}{l}\text { 2.2.My family does not want to } \\
\text { leave hometown and work far } \\
\text { away. }\end{array}$ & $\begin{array}{c}254 \\
(42.3 \%)\end{array}$ & $\begin{array}{c}4.17 \\
(0.47)\end{array}$ & 0 & 0 & $\begin{array}{c}11 \\
(4.3 \%)\end{array}$ & $\begin{array}{c}190 \\
(74.8 \%)\end{array}$ & $\begin{array}{c}53 \\
(20.9 \%)\end{array}$ \\
\hline $\begin{array}{l}\text { 2.3.My family just leave hometown } \\
\text { to work far away in the spare time } \\
\text { of the farming season }\end{array}$ & $\begin{array}{c}103 \\
(17.2 \%)\end{array}$ & $\begin{array}{c}4.57 \\
(0.50)\end{array}$ & 0 & 0 & 0 & $\begin{array}{c}44 \\
(42.7 \%)\end{array}$ & $\begin{array}{c}59 \\
(57.3 \%)\end{array}$ \\
\hline $\begin{array}{c}\text { 2.4. The young people of the family } \\
\text { all leave home to work far away. If } \\
\text { conditions permit, they are ready to } \\
\text { settle in a new workplace. }\end{array}$ & $\begin{array}{c}218 \\
(36.3 \%)\end{array}$ & $\begin{array}{l}4.73 \\
(0.44)\end{array}$ & 0 & 0 & 0 & $\begin{array}{c}58 \\
(26.6 \%)\end{array}$ & $\begin{array}{c}160 \\
(73.4 \%)\end{array}$ \\
\hline Total & $\begin{array}{c}600 \\
(100 \%)\end{array}$ & & & & & & \\
\hline \multicolumn{8}{|l|}{$\begin{array}{l}\text { 3.Application of science and } \\
\text { technology to agricultural } \\
\text { production }\end{array}$} \\
\hline $\begin{array}{l}\text { 3.1. My family hardly learns new } \\
\text { knowledge to apply in production. }\end{array}$ & $\begin{array}{c}79 \\
(13.2 \%)\end{array}$ & $\begin{array}{l}4.00 \\
(0.00)\end{array}$ & 0 & 0 & 0 & $\begin{array}{c}79 \\
(100 \%)\end{array}$ & 0 \\
\hline
\end{tabular}




\begin{tabular}{|c|c|c|c|c|c|c|c|}
\hline \multicolumn{8}{|l|}{$\begin{array}{l}\text { We still produce according to } \\
\text { traditional experiences }\end{array}$} \\
\hline $\begin{array}{l}\text { 3.2.My family hardly learns new } \\
\text { knowledge to apply in production. } \\
\text { We don't much apply science and } \\
\text { technology to production because } \\
\text { we cannot afford the capital and } \\
\text { production capacity. }\end{array}$ & $\begin{array}{c}345 \\
(57.5 \%)\end{array}$ & $\begin{array}{c}3.97 \\
(0.21)\end{array}$ & 0 & 0 & $\begin{array}{c}13 \\
(3.8 \%)\end{array}$ & $\begin{array}{c}329 \\
(95.4 \%)\end{array}$ & $\begin{array}{c}3 \\
(0.9 \%)\end{array}$ \\
\hline $\begin{array}{l}\text { 3.3.My family always learn, } \\
\text { explore and try to apply new } \\
\text { knowledge to cultivation and } \\
\text { husbandry to increase crop and } \\
\text { livestock productivity and sell } \\
\text { products to the market. }\end{array}$ & $\begin{array}{c}176 \\
(29.3 \%)\end{array}$ & $\begin{array}{l}4.00 \\
(0.00)\end{array}$ & 0 & 0 & 0 & $\begin{array}{c}176 \\
(100 \%)\end{array}$ & 0 \\
\hline Total & $\begin{array}{c}600 \\
(100 \%)\end{array}$ & & & & & & \\
\hline \multicolumn{8}{|l|}{ 4.Investment in production } \\
\hline $\begin{array}{l}\text { 4.1.My family is less interested in } \\
\text { investing in production, because } \\
\text { production is mainly for family } \\
\text { consumption }\end{array}$ & $\begin{array}{c}111 \\
(18.5 \%)\end{array}$ & $\begin{array}{c}4.22 \\
(0.41)\end{array}$ & 0 & 0 & 0 & $\begin{array}{c}87 \\
(78.4 \%)\end{array}$ & $\begin{array}{c}24 \\
(21.6 \%)\end{array}$ \\
\hline $\begin{array}{l}\text { 4.2.My family is less interested in } \\
\text { investing in production because we } \\
\text { cannot afford the capital and do not } \\
\text { dare to borrow from the bank for } \\
\text { fear of being unable to pay. }\end{array}$ & $\begin{array}{c}250 \\
(41.7 \%)\end{array}$ & $\begin{array}{l}3.97 \\
(0.27)\end{array}$ & 0 & 0 & $\begin{array}{c}13 \\
(5.2 \%)\end{array}$ & $\begin{array}{c}231 \\
(92.4 \%)\end{array}$ & $\begin{array}{c}6 \\
(2.4 \%)\end{array}$ \\
\hline $\begin{array}{l}\text { 4.3.My family is much interested in } \\
\text { investing in production, borrowing } \\
\text { from bank or relatives to invest in } \\
\text { production }\end{array}$ & $\begin{array}{c}239 \\
(39.8 \%)\end{array}$ & $\begin{array}{c}4.11 \\
(0.32 \%)\end{array}$ & 0 & 0 & 0 & $\begin{array}{c}212 \\
(88.7 \%)\end{array}$ & $\begin{array}{c}27 \\
(11.3 \%)\end{array}$ \\
\hline Total & $\begin{array}{c}600 \\
(100 \%)\end{array}$ & & & & & & \\
\hline \multicolumn{8}{|l|}{ 5.Product consumption } \\
\hline $\begin{array}{l}\text { 5.1.Agricultural products are } \\
\text { mainly produced for family } \\
\text { consumption, rarely for sale }\end{array}$ & $\begin{array}{c}27 \\
(4.5 \%)\end{array}$ & $\begin{array}{l}4.07 \\
(0.27)\end{array}$ & 0 & 0 & 0 & $\begin{array}{c}25 \\
(92.6 \%)\end{array}$ & $\begin{array}{c}2 \\
(7.4 \%)\end{array}$ \\
\hline $\begin{array}{l}\text { 5.2. Agricultural products are made } \\
\text { both for family consumption and } \\
\text { for sale on the market }\end{array}$ & $\begin{array}{c}353 \\
(58.8 \%)\end{array}$ & $\begin{array}{l}4.03 \\
(0.16)\end{array}$ & 0 & 0 & 0 & $\begin{array}{c}344 \\
(97.5 \%)\end{array}$ & $\begin{array}{c}9 \\
(2.5 \%)\end{array}$ \\
\hline $\begin{array}{l}\text { 5.3.Agricultural products are made } \\
\text { primarily for sale on the market }\end{array}$ & $\begin{array}{c}220 \\
(36.7 \%) \\
\end{array}$ & $\begin{array}{c}4.12 \\
(0.33 \%) \\
\end{array}$ & 0 & 0 & 0 & $\begin{array}{c}193 \\
(87.7 \%) \\
\end{array}$ & $\begin{array}{c}27 \\
(12.3 \%) \\
\end{array}$ \\
\hline P & $\begin{array}{c}600 \\
(100 \%)\end{array}$ & & & & & & \\
\hline
\end{tabular}

Table 4 shows that in all 5 aspects relating to the farmers' behaviors, the majority of respondents chose the second item, which can be seen from the far higher percentage of choice than the other 2 items in all 5 questions. Thus, the behavior of traditional agriculture is gradually changing to meet the requirements of the market economy. The rate of selecting the first item is lowest in the aspects of "attachment to fields and homeland" $(4.2 \%, \mathrm{M}=4.08)$ and "product consumption" (4.5\%, $\mathrm{M}=4.07)$, showing the most significant behavioral change in the decreased attachment to traditional farming and decreased behavior of producing for household consumption only. Remarkably, in terms of behaviors of attachment to the fields and homeland, while the rate of choosing adhering to the fields and traditional jobs is only $4.2 \%$, the rate of choosing not to leave the homeland to work far away is high (42.3\%), indicating a certain variation in farmers' behavior. Farmers do not want to leave their homeland, but they do not continue farming, instead, they switch to other forms of production that are more suitable to market mechanisms. The rate of selecting the third item in all questions are relatively similar, ranging from $29.3 \%$ to $39.8 \%$, showing that the change in behavior is quite noticeable in all aspects. This rate of selecting the third item is also much higher than the rate of choosing the third item on the 
subset of perception and emotional change. This result implies that the change in the behavior of farmers in response to market mechanisms is most intense. following are changes in perceptions and emotions.

\subsection{Factors affecting farmers' psychological change}

We tested the impact of 5 influencing factors: gender, age, academic level, place of residence and living standard on farmers' psychological change by using multivariate regression models. The results are shown in Table 5.

Table 5. Factors affecting farmers' psychological change

\begin{tabular}{|c|c|c|c|c|c|c|}
\hline & \multicolumn{2}{|c|}{ Perception } & \multicolumn{2}{c|}{ Emotion } & \multicolumn{2}{c|}{ Behavior } \\
\cline { 2 - 7 } & $\beta$ & $\mathrm{p}$ & $\beta$ & $\mathrm{p}$ & $\beta$ & $\mathrm{p}$ \\
\hline Gender (ref. Male) & .083 & .004 & .124 & .000 & .011 & .648 \\
\hline Age (ref. 50-70 years old) & & & & & & \\
\hline$<30$ years old & -.167 & .001 & -.080 & .062 & -.045 & .285 \\
\hline $40-49$ years old & -.095 & .086 & -.002 & .966 & -.055 & .238 \\
\hline $\begin{array}{c}\text { Academic level (ref. post- } \\
\text { secondary level) }\end{array}$ & & & & & & \\
\hline Primary & -.219 & .000 & -.335 & .000 & -.160 & .001 \\
\hline Lower secondary & -.272 & .000 & -.412 & .000 & -.143 & .020 \\
\hline Upper secondary & -.252 & .000 & -.241 & .000 & -.130 & .019 \\
\hline $\begin{array}{c}\text { Place of residence (ref. } \\
\text { mountainous rural areas) }\end{array}$ & & & & & & \\
\hline Delta rural areas & .291 & .000 & .553 & .000 & .522 & .000 \\
\hline Suburban rural areas & .188 & .000 & .719 & .000 & .891 & .000 \\
\hline $\begin{array}{c}\text { Living standard (ref. } \\
\text { inadequate group) }\end{array}$ & \multicolumn{2}{|c|}{} & & & & \\
\hline Well off & -1.030 & .000 & -.430 & .000 & -.072 & .159 \\
\hline Adequate & -.894 & .000 & -.397 & .000 & .017 & .743 \\
\hline p-value & $<0.001$ & $<0.001$ & & $<0.001$ \\
\hline R2 & \multicolumn{2}{|c|}{0.584} & \multicolumn{2}{c|}{0.693} & \multicolumn{2}{c|}{0.700} \\
\hline
\end{tabular}

Men are more likely to change perceptions $(\beta=0.083, \mathrm{p}<0.01)$ and emotions $(\beta=$ $0.124, \mathrm{p}<0.01)$ than women.

Age has little effect on psychological change. Young people under 30 years old are the group with the most significant change in perceptions $(\beta=-0.167, \mathrm{p}<0.01)$. However, there is not much change in emotions and behaviors; meanwhile, middle-aged and old age groups do not show much difference in psychological changes in all three aspects. In other words, the younger the age, the more likely the perception change is.

Academic level clearly affects the change in psychology. The higher the education level, the more evident the change in perceptions, emotions and behaviors. This is reflected in the negative score $\beta$ when comparing between the post-secondary farmers and other groups.

Regarding place of residence, farmers in the delta have the most significant changes in awareness $(\beta=0.291, p<0.01)$, the peri-urban areas have the most significant changes in emotion $(B=0.719, \mathrm{p}<0.01))$ and behavior $(\beta=0.891, \mathrm{p}<0.01)$, while farmers in mountainous areas have the least change. Thus, the closer people are to urban areas, the more likely they are to change their thinking, emotions and behaviors in agricultural production.

Living standards affect changes in perceptions and emotions but do not affect changes in farmers' behavior. The higher the standard of living among farmers, the change is much stronger than those of the deprived ones. 
Taken all together, these five factors help explain $58 \%-70 \%$ of the variation as the level of changes in farmers' perceptions, emotions and behaviors. This shows the good predictability of the current 5 -element model.

\section{Conclusion}

Research on psychological changes of farmers in Vietnam in the context of implementing the market mechanism shows that Vietnamese farmers in the sample have certain psychological changes. Most farmers think that their families need to restructure livestock and crops so that the products can be sold in the market. In terms of emotional changes, farmers reduce their attachment to the fields and their homeland to engage in new jobs with better economic value, reduce their attachment to traditional values to move towards new values. In terms of behavioral changes, the change in behavior is most pronounced in reduced attachment to traditional farming and reduced behavior of producing only for household consumption. Of the three aspects of perception, emotion and behavior, the change in behavior is most obvious.

\section{References}

1. H. Binswanger- Mkhize, Afr. J. Agri. Res. Econ. 9, 253 (2014)

2. W. Anseeuw, N. Mathebula, TIPS Annual Forum: South Africa.s economic miracle (2008)

3. J. Davis, Int. Bus. Econ. Res. J. 10, 201 (2011)

4. P. Jacobs, E. Lahiff, R. Hall, Foundation for Human Rights in South Africa (2003)

5. A. Djurfeldt, World Dev. 41, 217 (2013)

6. P. Dorosh, S. Rashid, Food and Agriculture in Ethiopia: Progress and policy challenges (University of Pennsylvania press, 2013)

7. O. Ecker, C. Breisinger, IFPRI Discussion Paper 01166 (2012)

8. R. Goswami, S. Chatterjee, B. Prasad, Agri Food Econ. 2, 5 (2014)

9. A. Chapoto, A. Mabiso, A. Bonsu, Ghana International Food Research Institute Discussion Paper 01286 (2013)

10. J. Richards, J. Voca. Beh. 3, 485 (1973)

11. A. Brayfield, M. Marsh, J. Appl. Psychol. 41, 98 (1957)

12. V. Oliveira, J. Sorensen, P. Thomsen, Vet. Rec. 182, 325 (2017)

13. S. Guerrier, Farmers, farming \& change: A social psychological analysis (University of London, London, 2007)

14. S. Yazd, S. Wheeler, A. Zuo, Int. J. Environ. Res. Public Health 16, 4849 (2019)

15. U. Chipfupa, E. Wale, Dev. Pract. 28, 600 (2018)

16. L. Do, H. Tran, Village community psychology and heritage (Social Science Publishing House, Hanoi, 1993)

17. D. Vu, Understanding some typical psychological aspects of workers from neighboring provinces in Hanoi (Institute of Psychology, Hanoi, 1999)

18. D. Tran, Female labor migration from rural areas to cities: Female venders from neighboring provinces in Hanoi (University of Social Sciences and Humanities, Hanoi, 2006) 
19. H. Phan, Psychological changes of urbanized peri-urban residents (Institute of Psychology, Hanoi, 2006)

20. D. Vu, Ethnic psychological factors affecting the development in the Central Highlands (Institute of Psychology, Hanoi, 2006)

21. D. $\mathrm{Vu}$, The basic psychological characteristics of communities in the Central Highlands and the Southwest region and, their influence on the socio-economic development in this region (Institute of Psychology, Hanoi, 2006)

22. D. Vu, The psychological characteristics of ethnic minorities in the Northwest region and their influence on the stability and development of this region (Institute of Psychology, Hanoi, 2008)

23. H. Nguyen, Basic psychosocial characteristics of Vietnamese peasantry (Institute of Psychology, Hanoi, 2010)

24. D. Bui, Investigation report on Vietnamese farmers in 2009 (Vietnam Academy of Social Sciences, Hanoi, 2009)

25. T. Truong, A social attitutes survey of farmers in the Northern Delta on Vietnam's accession to the WTO (Vietnam Academy of Social Sciences, Hanoi, 2010)

26. H. Luu, Psychological issues of farmers who had land acquired for industrial parks (Vietnam Academy of Social Sciences, Hanoi, 2007)

27. L. Nguyen, Basic psychological issues of poor farmers in the Northwestern mountainous region (Vietnam Academy of Social Sciences, Hanoi, 2008)

28. D. Bui, Investigation report on Vietnamese farmers in 2010 (Vietnam Academy of Social Sciences, Hanoi, 2011)

29. D. Vu, Mechanisms and policies to support disadvantaged farmers in the transition to a market economy (Social Science Publishing House, Hanoi, 2012)

30. D. Vu, Current employment, income of young people (Bach Khoa Dictionary Publishing House, Hanoi, 2012)

31. D. Vu, Social adaptation of disadvantaged social groups in Vietnam (Bach Khoa Dictionary Publishing House, Hanoi, 2012)

32. D. Vu, Environmental ethics in Vietnam- Theory and practice (Bach Khoa Dictionary Publishing House, Hanoi, 2011)

33. D. Vu, Psychological characteristics of Ethnic Minority Protestant Community in the Central Highlands (Labor Publishing House, Hanoi, 2014)

34. H. Le, Psychological factors of farmers affecting the process of building a new rural areas in the Northern Delta (Institute of Psychology, Hanoi, 2014)

35. T. La, A study on the psychological changes of residents in the transition zone from commune to ward (Institute of Psychology, Hanoi, 2014)

36. H. Phan, Research on the efforts of farmers to get out of poverty (Institute of Psychology, Hanoi, 2016)

37. A. Bui, Studying and evaluating the interaction of farmers' psychology with the transformation of modern agricultural production methods (Vietnam Academy of Social Sciences, Hanoi, 2016)

38. T. Nguyen, Gender stereotypes about female farmers' personalities in the Red River Delta.(University of Social Sciences and Humanities, Hanoi, 2016)

39. T. La, The phenomenon of farmers leaving fields in the Northern Delta region Psychological aspects (Institute of Psychology, Hanoi, 2016) 